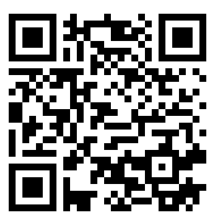

Submitted:

06-11-2019
Revised:

20-11-2019
Journal An-Nafs: Kajian Penelitian Psikologi

https://ejournal.iai-tribakti.ac.id/index.php/psikologi e-ISSN: 2549-6166 p-ISSN: 2528-0600

DOI: $10.33367 / p s i . v 5 i 2.956$

\title{
EFEKTIVITAS PELATIHAN EMOTIONAL INTELLIGENCE UNTUK MENINGKATKAN RESILIENSI PADA SISWA SMP YANG MELAKUKAN SELF INJURY
}

\author{
${ }^{1}$ Lebda Katodhia, ${ }^{2}$ Frikson C. Sinambela \\ 1katodhialebda@gmail.com,2friksonsinambela@gmail.com \\ Universitas Surabaya
}

\begin{abstract}
The rise of the case of middle school students who commit acts of self-injury creates new problems in education. The cause is a lack of resilience in self. When this condition is left constantly, it will have an impact on psychological problems. This study aims to understand the effectiveness of emotional intelligence training in enhancing students' resilience in SMP X Surabaya. The method used in this experimental study is a single case experimental design. There were 19 female students have been doing self-injury such as slashing their hands. First, The Resilience Scale is used to assess students' resilience and The Assessing Emotions Scale Mayor-Salovey is used for assessing emotional intelligence. Second, the result analyzed with Paired Sample T-test. Third, Linear Regression Analysis conducted to examine the effect the training on students' resiliency. In the follow-up stage, the data analyzed using a Wilcoxon Signed Rank. The emotional intelligence training gave in 4 sessions within 2 days. Besides, in the follow-up stage, participants are interviewed. The result shows statistical significance of 0.009 ( $p$ < 0.05). It conveys there is a significant difference in students' resilience levels before and after the training. The significant results of the training lasted until the follow-up one week after the training. The existence of emotional intelligence makes the participants more persistent and resilient in dealing with daily problems so that the participants will not repeat their self-harming behavior.
\end{abstract}

Keywords: Self-injury, Emotional intelligence training, Students' resiliency

\begin{abstract}
Abstrak
Maraknya kasus siswa SMP yang melakukan tindakan menyakiti diri sendiri (Self Injury) membuat permasalahan baru dalam dunia pendidikan. Penyebabnya bermacam-macam dan mengarah pada kurangnya resilensi dalam diri. Ketika kondisi ini dibiarkan terusmenerus, maka akan berdampak pada permasalahan psikologis. Penelitian ini bertujuan untuk meningkatkan resiliensi pada siswa SMP X di Surabaya melalui pelatihan kecerdasan emosi (emotional intelligence). Penelitian ini menggunakan metode eksperimen single case experimental design dengan total partisipan berjumlah 19 siswi SMP X Surabaya yang menyilet tangannya (self injury). Resiliensi diukur menggunakan skala RS (The Resilience Scale) dan kecerdasan emosi diukur menggunakan skala The Assessing Emotions Scale Mayer-Salovey, kemudian dianalisis menggunakan Paired Sample T-test. Follow up dianalisis menggunakan statistik Wilcoxon Signed Rank. Pelatihan kecerdasan emosi dilakukan selama empat sesi yang dilaksanakan dua hari. Hasil analisis kuantitatif data menunjukkan nilai signifikansi 0.009 ( $\mathrm{p}<0.05)$. Hal ini berarti terdapat perbedaan yang signifikan pada tingkat resiliensi diri siswa sebelum dan setelah pemberian pelatihan. Dengan demikian dapat dikatakan bahwa tingkat resiliensi peserta meningkat setelah pemberian pelatihan kecerdasan emosi. Adanya emotional intellgence membuat para peserta semakin gigih atau resilien dalam menghadapi permasalahan
\end{abstract}


sehari-hari, sehingga membuat peserta tidak akan mengulangi perilaku menyakiti diri sendiri.

Kata kunci: Menyakiti diri sendiri, Pelatihan kecerdasan emosi, Resiliensi siswa

\section{PENDAHULUAN}

Siswa merupakan sekelompok orang dengan usia tertentu yang belajar baik secara kelompok/ perorangan atau juga dapat dikatakan sebagai murid atau pelajar yang berada di lingkungan sekolah, baik Sekolah Dasar (SD), Sekolah Menengah Pertama (SMP), dan Sekolah Menengah Atas (SMA) (Jawa pos, 1949, dalam Ali, 2010). Secara keseluruhan dapat dijelaskan bahwa siswa adalah status yang disandang oleh seseorang karena hubungannya dengan dunia pendidikan yang diharapkan menjadi calon-calon intelektual untuk menjadi generasi penerus bangsa (Ali, 2010).

Di Indonesia, hampir seluruh daerah baik kecamatan maupun kelurahan memiliki Sekolah di dalamnya, yang terdiri dari SD, SMP, dan SMA. Banyaknya sekolah yang berada di Indonesia sejalan dengan banyaknya permasalahan yang ada, salah satunya adalah tindakan self injury dengan menyilet tangan yang dilakukan siswa-siswi SMP (Tirto.id, 2018). Menurut penelitian Alfonso dan Dedrick (2014), prevalensi remaja melakukan tindakan menyakiti diri sendiri mencapai 28.4\% (Alfonso \& Dedrick, 2010). Tindakan melukai diri sendiri (self injury) adalah bentuk perilaku yang sengaja dilakukan oleh seseorang untuk melukai dirinya sendiri tanpa bermaksud untuk bunuh diri guna mengurangi penderitaan secara psikologis, tindakan tersebut dapat berupa menyayat bagian kulit tubuh dengan pisau atau silet, memukul diri sendiri, memotong rambut, dan lain sebagainya (Estefan \& Wijaya, 2014).

Penyebab seseorang melakukan self injury bermacam-macam, menurut hasil wawancara yang dilakukan kepada salah satu partisipan yaitu siswa SMP X di Surabaya yang melakukan self injury, diketahui bahwa tindakan menyilet tangan disebabkan oleh kurangnya rasa mencintai diri sendiri, kurangnya kemampuan dalam berpikir dampak dari tindakan yang dilakukan, kurangnya kekuatan dalam menghadapi persoalan, kurangnya pemahaman siswa akan perubahan emosi, kurangnya keyakinan diri untuk berubah menjadi lebih baik, dan kurangnya pengetahuan siswa akan adanya alternatif lain dalam menyelesaikan suatu persoalan. Penyebab-penyebab ini merupakan aspek dari resiliensi atau ketahanan. Resiliensi umumnya mewakili kapasitas untuk "bounce back" stres atau pesoalan lainnya secara efektif, beradaptasi secara fleksibel dan bahkan tumbuh secara positif dengan menanggapi secara positif kesulitan dalam diri (Liu, Wang, \& Lü, 2013). 
Menurut Wagnild dan Young (1993) resiliensi ialah kemampuan seseorang untuk beradaptasi dalam menghadapi kesulitan hidup. Seseorang yang resilien, maka akan dapat bangkit dari keterpurukannya atau kesulitan dalam hidupnya. Resiliensi dapat terbentuk karena dipengaruhi oleh 2 faktor yaitu faktor eksternal meliputi pengalaman masa kecil, seperti hubungan dekat dengan lingkungan, peran model yang dapat menimbulkan kebahagiaan dan kemandirian dan kontribusi dari dukungan keluarga secara efektif (Wagnild \& Young, 1993). Faktor internal merupakan faktor yang berasal dari dalam diri seseorang (karakteristik seseorang).

Pentingnya resiliensi bagi siswa perempuan yang melakukan self injury adalah agar siswa memiliki daya tahan dan mampu menghadapi semua tantangan dalam hidup dan pendidikan. Siswa yang memiliki daya tahan kuat dapat membuat kondisi yang tidak kondusif sebagai tantangan dan bukan merupakan kendala atau masalah bagi mereka. Kuipera (2012) merujuk resiliensi sebagai bagian dari psikologi positif yang mengarahkan individu untuk memaknai kembali kualitas hidup dan mengarahkannya pada gaya hidup yang positif agar individu menjadi lebih resilien dalam menghadapi stress yang menimpa (Kuipera, 2012).

Siswa yang melakukan self injury adalah para remaja yang sedang berada pada tahap pencarian identitas. Remaja merupakan masa peralihan dari masa kanak-kanak ke masa dewasa. Masa peralihan ini mengkibatkan terjadinya perubahan secara fisik maupun psikis. Masa ini juga banyak menimbulkan kesulitan dalam penyesuaian diri terhadap situasi di lingkungan. Adapula yang mengatakan bahwa masa remaja adalah suatu masa peralihan yaitu periode masa transisi antara masa kanak-kanak dan dewasa yang mensyaratkan suatu perubahan-perubahan biologis, kognitif dan psikososial individu (Santrock, 2001). Dalam masa ini remaja dituntut untuk menyesuaikan diri terhadap peranan barunya baik secara psikis maupun sosial. Remaja masih akan mengalami peningkatan emosional, terutama ketika ia menghadapi situasi yang tegang dan bimbang.

Salah satu cara untuk meningkatkan resiliensi agar remaja mudah beradaptasi, tidak tegang dan bimbang dalam menghadapi persoalan adalah dengan melakukan pelatihan emotional intelligence (EI). Emotional intelligence atau kecerdasan emosional merupakan tipe dari kecerdasan sosial yang melibatkan kemampuan untuk memonitor emosi diri dan orang lain, membedakan jenis emosi tersebut dan menggunakannya untuk mengerahkan pikiran dan kemampuan dirinya sendiri. Kemudian definisi ini disempurnakan dan dipecah menjadi empat bagian kemampuan yang berbeda namun tetap berkaitan, yaitu: mengamati, menggunakan, memahami, dan mengelola emosi (Mayer, J. D., \& Salovey, 1997). 
Kecerdasan emosional merupakan dasar penting dalam menjadikan individu sebagai seseorang yang mampu menghadapi tantangan dan mempertahankan semangat hidupnya. Kecerdasan emosional diperlukan apabila individu menghadapi masalah yang dapat menimbulkan tekanan agar individu tersebut dapat mengendalikan emosi yang dimilikinya sehingga dapat menghadapi masalah dengan baik (Shapiro, 1997).

Terdapat bukti kuat yang mendukung asosiasi antara resiliensi/ ketahanan dan EI (Liu, dkk., 2013). Armstrong et, al (2011) melakukan penelitian yang mengungkapkan bahwa individu yang rentan memiliki skor EI yang lebih rendah, sedangkan individu yang memiliki resiliensi/ ketahanan memiliki skor EI yang lebih tinggi (Armstrong, Galligan, \& Critchley, 2011). Lebih dari itu, inti dari EI adalah kemampuan efektif untuk mengatur emosi seseorang, yang ditemukan dapat meningkatkan ketahanan/ resiliensi individu (New et al., 2009; Tugade \& Fredrickson, 2007). Apor et, al (2015) dalam penelitiannya menemukan hubungan positif antara resiliensi/ ketahanan dan sebagian besar cabang EI (Frajo-Apor, Pardeller, Kemmler, \& Hofer, 2016).

Berdasarkan hasil wawancara dengan Kepala SMP X Surabaya, guru bimbingan konseling, dan siswa yang melakukan self injury, upaya yang dapat dilakukan untuk meningkatkan resiliensi siswa adalah dengan melakukan pelatihan emotional intelligence. Metode pelatihan dianggap merupakan pilihan yang sesuai untuk dapat meningkatkan kemampuan siswa agar siswa mampu lebih beradaptasi dan tetap bangkit ketika menghadapi persoalan dalam hidup, baik persoalan eksternal maupun internal dalam diri. Metode pelatihan merupakan metode yang cukup efektif untuk meningkatkan motivasi, menambah pengetahuan pada level kognitif, memodifikasi sikap, dan menambah keterampilan berperilaku (Sahrah \& Yuniasanti, 2018).

Pelatihan sebagai perlakuan atau intervensi untuk modifikasi perilaku yang direncanakan dan sistematis melalui kegiatan pembelajaran agar peserta mencapai tingkat pengetahuan, keterampilan, kompetensi dan kemampuan untuk melaksanakan pekerjaan mereka secara efektif (Betcherman, 1998, dalam Sahrah \& Yuniasanti, 2018). Pelatihan Emotional Intelligence, diartikan sebagai suatu program kegiatan pembelajaran yang terencana secara sistematis yang bertujuan agar siswa atau peserta dapat mencapai tingkat pengetahuan dan keterampilan untuk menumbuhkan resiliensi dalam dirinya (Betcherman, 1998, dalam Sahrah \& Yuniasanti, 2018). Di Indonesia, belum ada penelitian terkait pelatihan emotional intelligence yang khusus meningkatkan resiliensi, beberapa penelitian hanya mengungkapkan bahwa kecerdasan emosi atau emotional intelligence memiliki hubungan yang positif dengan resiliensi, salah satunya adalah penelitian yang dilakukan oleh Setyowati, Hartati, dan Sawitri (2010) yang menyimpulkan bahwa salah 
satu faktor yang berkontribusi terhadap resiliensi pada siswa pengguna NAPZA adalah kecerdasan emosional (Setyowati, Hartati, \& Sawitri, 2010).

Penelitian ini bertujuan untuk mengetahui efektivitas pelatihan emotional intelligence dalam meningkatkan resiliensi siswa SMP yang melakukan tindakan menyakiti diri sendiri. Hipotesis yang diajukan dalam penelitian ini adalah bahwa pelatihan emotional intelligence efektif untuk meningkatkan resiliensi pada siswa yang melakukan self injury.

\section{METODE}

Peserta pelatihan berjumlah 19 siswa perempuan gabungan dari kelas 7 dan 8 yang saat ini tercatat aktif sebagai siswa yang bersekolah di SMPN X Surabaya dan melalui wawancara mengungkapkan ikut melakukan self injury atau perilaku menyakiti diri sendiri dengan cara melukai tangan menggunakan silet, sehingga membentuk garis-garis bekas luka. 19 peserta pelatihan ini merupakan siswa yang merasa puas dari perilaku self injury yang mereka lakukan, dan disebabkan oleh masalah eksternal misalnya orang tua atau teman-teman di sekolah.

Pelatihan ini menggunakan beberapa metode penyampaian materi yang bertujuan untuk mempermudah pemahaman peserta akan materi yang diberikan. Beberapa metode tersebut antara lain adalah audio visual (penayangan video yang sesuai dengan materi), lecturing (menjelaskan isi materi), paper assignment (pemberian tugas-tugas), permainan, diskusi, refleksi, dan self record.

Penelitian ini menggunakan pendekatan eksperimen dengan one group pretestposttest design, yaitu perkembangan dari desain satu kelompok. Pada awal penelitian, dilakukan pengukuran (pre-test), kemudian dilanjutkan dengan pemberian perlakuan (treatment), dan setelah itu akan dilakukan kembali pengukuran (post-test) dengan alat ukur yang sama. Desain eksperimen dapat dilihat pada tabel 1.

\begin{tabular}{ccc}
\hline Pre-test & Perlakuan & Post-test \\
\hline 01 & $\mathrm{X}$ & 02 \\
\hline
\end{tabular}

Keterangan:

01 : Pretest sebelum pelatihan dilakukan

$\mathrm{X} \quad$ : Pelatihan emotional intelligence

02 : Posttest setelah pelatihan

Penelitian ini dilakukan dalam tiga tahapan. Pada tahap pertama dilakukan pretest dimana peserta akan mengisi angket The Resilience Scale (RS). RS terdiri dari 25 aitem pernyataan dengan 7 pilihan respon, yaitu 1 = "Tidak setuju" sampai 7= "Setuju". RS memiliki reliabilitas alpha cronbach sebesar 0.91 dengan Test-retest $(r=0.67-0.84)$. 
Validitas yang diuji untuk alat ukur ini adalah content validity, construct validity, dan concurrent validity. Tahap ini diperlukan untuk membandingkan skor resiliensi peserta sebelum dan setelah pelatihan berlangsung.

Alat ukur emotional intelligence menggunakan The Assessing Emotions Scale Mayer-Salovey yang terdiri dari 33 pernyataan dengan 5 pilihan respon, yaitu 1= "sangat tidak setuju", 2= "tidak setuju", 3="netral", 4="setuju", dan 5="sangat setuju". The Assessing Emotions Scale memiliki reliabilitas alpha cronbach sebesar 0.90. Test-retest reliability sebesar 0.78. setelah itu dilakukan uji regresi linear untuk mengetahui besar pengaruh pelatihan emotional intellgence untuk menurunkan resiliensi siswa.

Tahap kedua merupakan tahap treatment, pada tahap ini pelatihan diberikan. Penyusunan modul pelatihan emotional intellgence menggunakan acuan empat aspek emotional intellgence yang dikemukakan oleh Mayer-Salovey (1997), yaitu perceiving emotions, using emotions, understanding emotions, dan managing emotions. Aspek-aspek kecerdasan emosi kemudian dijabarkan ke dalam sesi-sesi pelatihan sehingga sesi pelatihan dibagi menjadi empat (Campo, Laborde, \& Weckemann, 2015). Sesi 1, Perceiving Emotions, yang meliputi materi mengenai kemampuan untuk bergantung pada diri sendiri dan mengenal kekuatan serta keterbatasan dirinya. Sesi 2, Using Emotions, meliputi materi mengenai penantuan makna dan tujuan hidup. Sesi 3, Understanding Emotions, yang meliputi materi mengenai equanimity dan existensial aloneness, dimana individu harus memahami dan menyadari bahwa hidup adalah sebuah keseimbangan, kadang manusia memungkinkan untuk berada di atas, namun kadang menjadi mungkin berada di bawah, baik pada aspek finansial maupun aspek lainnya. Selain itu, memahami keunikan individu juga merupakan hal penting dilatih. Sesi 4, Managing Emotions, yang meliputi materi mengenai tindakan dalam bentuk ketekunan meskipun dalam situasi sulit dan kehilangan semangat.

Pada pelaksanaan pelatihan terdiri dari tiga tahapan pelaksanaan pelatihan yaitu tahap perkenalan, tahap inti, dan tahap akhir atau penutup. Pada tahap perkenalan meliputi pengisian absen, pretest, dan ice breaking. Pada tahap inti adalah pemberian pelatihan pada 4 sesi. Pada tahap akhir pelatihan atau penutup meliputi kesimpulan pelatihan dan evaluasi. Peserta pelatihan dapat mengungkapkan hal yang diperoleh dari pelatihan untuk dapat diterapkan dalam kehidupan sehari-hari.

Tahap pasca eksperimen berupa pemberian posttest pada peserta pelatihan yang telah diberi treatment dan yang telah mengisi pretest. Analisis data statistik menggunakan paired samplet $T$-test karena persebaran datanya normal. Kemudian setelah satu minggu, 
peserta yang mengalami penurunan skor pretest dan posttest akan di follow up menggunakan metode wawancara.

\section{PAPARAN HASIL}

Siswa yang mengikuti pelatihan berjumlah 19 orang, berjenis kelamin perempuan, dan memiliki usia rata-rata 12-15 tahun. Dari hasil evaluasi reaksi terhadap pelatihan, dapat disimpulkan bahwa peserta memberikan nilai rata-rata 4,8 untuk keterampilan sesuai perbaikan diri. Hal ini berarti rata-rata peserta berpikir bahwa keterampilan yang diajarkan dalam pelatihan ini sangat cocok untuk perbaikan diri mereka.

Selain itu, mereka juga memberikan nilai rata-rata 4,7 untuk kebermanfaatan materi. Dimana hal tersebut berarti seluruh peserta beranggapan bahwa isi materi selama pelatihan tersusun rapi dan bermanfaat bagi mereka. Nilai rata-rata 4,6 diberikan untuk paham tujuan dan materi mudah dipahami, hal ini berarti seluruh peserta merasa bahwa mereka memahami tujuan diadakannya pelatihan dan merasa penyampaian materi menggunakan contoh-contoh yang mudah dipahami.

Nilai rata-rata 4,5 diberikan pada energi sepadan dengan hasil dan mudah dipraktekkan dimana artinya peserta merasa bahwa tenaga dan waktu yang mereka luangkan sepadan dengan hasil pengetahuan dan ketrampilan yang mereka dapat dari pelatihan ini serta merasa materi dalam pelatihan mudah untuk dipraktekkan dalam kehidupan sehari-hari mereka dalam menghadapi permasalahan. Peserta juga merasa isi pelatihan merupakan yang mereka butuhkan. Hal tersebut dibuktikan dengan pemberian nilai rata-rata 4,4 dari hasil keseluruhan peserta.

Diagram 1 Tingkat pemahaman peserta terhadap materi pelatihan

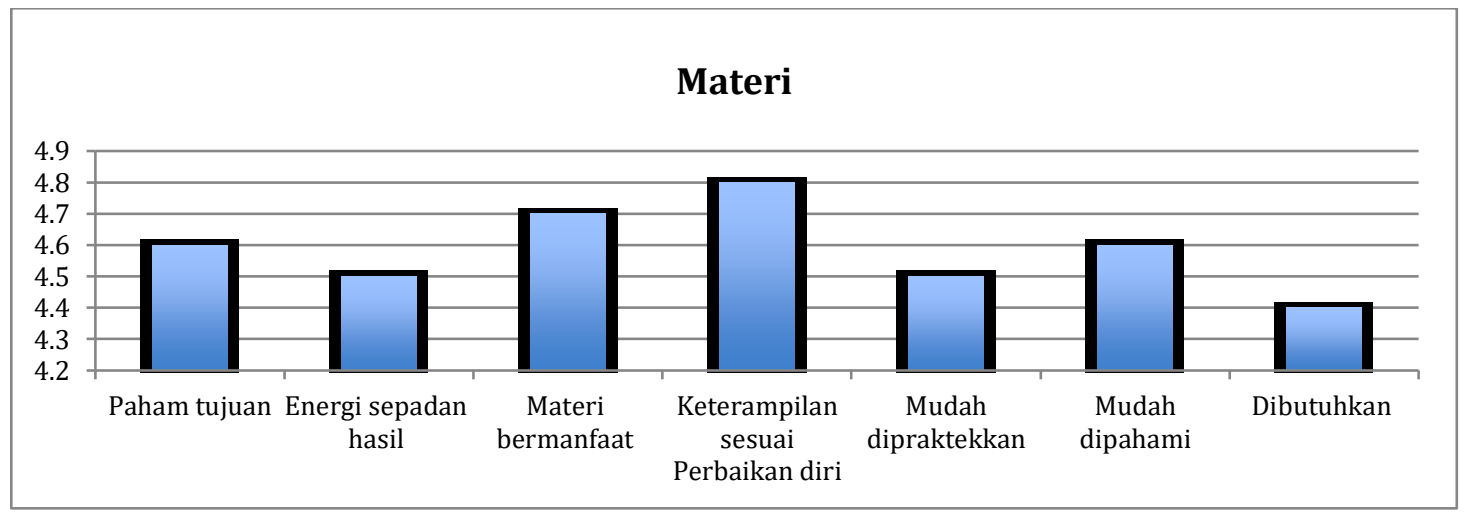

Pada penilaian level pengetahuan, seluruh peserta baik sebelum dan setelah pelatihan mengalami peningkatan kategori dari Sangat Rendah ke Sangat Tinggi (Tabel 2) dengan rata-rata skor pre test 3,7 dan post test 7,9. Hanya terdapat 5.2\% peserta yang memiliki kategori tetap dari pre test ke post test. 
Pengkategorian dilakukan dengan membuat norma ideal sebagai berikut:

Tabel 1 Norma Total Skor Knowledge

\begin{tabular}{cc}
\hline Skor & Kategori \\
\hline $20-80$ & Sangat Tinggi \\
$40-50$ & Tinggi \\
$20-30$ & Cukup \\
$\leq 10$ & Rendah \\
\hline
\end{tabular}

Berdasarkan norma ideal tersebut, berikut adalah gambaran perubahan kategori skor total pengetahuan setiap peserta dari pre test ke post test:

Tabel 2 Skor Total dan Perubahan Kategori Knowledge

\begin{tabular}{|c|c|c|c|c|c|c|c|}
\hline \multirow{2}{*}{ No } & \multirow{2}{*}{ Peserta } & \multicolumn{2}{|c|}{ Pre Test } & \multicolumn{2}{|c|}{ Post Test } & \multirow{2}{*}{$\begin{array}{l}\text { Perubahan } \\
\text { Skor }\end{array}$} & \multirow{2}{*}{ Keterangan } \\
\hline & & Skor & Kategori & Skor & Kategori & & \\
\hline 1 & A & 10 & SR & 80 & ST & 70 & Naik \\
\hline 2 & B & 40 & $\mathrm{C}$ & 100 & ST & 60 & Naik \\
\hline 3 & $\mathrm{C}$ & 20 & $\mathrm{R}$ & 80 & ST & 60 & Naik \\
\hline 4 & D & 10 & SR & 70 & $\mathrm{~T}$ & 60 & Naik \\
\hline 5 & $\mathrm{E}$ & 60 & $\mathrm{~T}$ & 70 & $\mathrm{~T}$ & 10 & Naik \\
\hline 6 & F & 20 & $\mathrm{R}$ & 80 & ST & 60 & Naik \\
\hline 7 & G & 30 & $\mathrm{R}$ & 80 & ST & 50 & Naik \\
\hline 8 & $\mathrm{H}$ & 40 & $\mathrm{C}$ & 100 & ST & 60 & Naik \\
\hline 9 & I & 50 & $\mathrm{C}$ & 70 & $\mathrm{~T}$ & 20 & Naik \\
\hline 10 & $\mathrm{~J}$ & 80 & ST & 80 & ST & 0 & Tetap \\
\hline 11 & $\mathrm{~K}$ & 10 & SR & 100 & ST & 90 & Naik \\
\hline 12 & $\mathrm{~L}$ & 20 & $\mathrm{R}$ & 90 & ST & 70 & Naik \\
\hline 13 & M & 30 & $\mathrm{R}$ & 70 & $\mathrm{~T}$ & 40 & Naik \\
\hline 14 & $\mathrm{~N}$ & 30 & $\mathrm{R}$ & 40 & $\mathrm{C}$ & 10 & Naik \\
\hline 15 & 0 & 50 & $\mathrm{C}$ & 70 & $\mathrm{~T}$ & 20 & Naik \\
\hline 16 & $\mathrm{P}$ & 50 & $\mathrm{C}$ & 80 & ST & 30 & Naik \\
\hline 17 & $Q$ & 60 & $\mathrm{~T}$ & 80 & ST & 20 & Naik \\
\hline 18 & $\mathrm{R}$ & 40 & $\mathrm{C}$ & 80 & ST & 40 & Naik \\
\hline 19 & $\mathrm{~S}$ & 50 & $\mathrm{C}$ & 90 & ST & 40 & Naik \\
\hline \multicolumn{2}{|c|}{ Rata-rata } & 36,8 & & 79,4 & & & \\
\hline
\end{tabular}

Sebelum data dianalisis, hal utama yang harus dilakukan terlebih dahulu adalah uji asumsi, yaitu uji normalitas dan uji homogenitas untuk melihat normal atau tidaknya perserabaran data pretest dan posttest. Berikut hasil uji normalitas dan uji homogenitas pre test dan post test emotional intelligence:

Tabel 3 Uji Normalitas Pre Test dan Post Test Emotional Intelligenc

\begin{tabular}{|llr|r|}
\hline & & Pretest & Post Test \\
\hline $\mathrm{N}$ & & 19 & 19 \\
Normal Parameters & & \\
& Mean & 124.4211 & 124.4211 \\
& Std. Deviation & 13.65575 & 13.65575 \\
Most Extreme & Absolute & .249 & .249 \\
Differences & Positive & .249 & .249 \\
& Negative & -.116 & -.116
\end{tabular}


Lebda Katodhia \& Frikson C. Sinambela | Efektivitas Pelatihan Emotional

\begin{tabular}{|lr|r|} 
Kolmogorov-Smirnov Z & .704 & 1.086 \\
Asymp. Sig. (2-tailed) & .705 & .189 \\
\hline
\end{tabular}

Test of Homogeneity of Variances
EI
\begin{tabular}{|cccc|}
\hline Levene Statistic & df1 & df2 & Sig. \\
\hline 1.130 & 1 & 36 & .295 \\
\hline
\end{tabular}

Berdasarkan uji normalitas (Tabel 3), diketahui bahwa data pretest dan posttest memiliki persebaran data yang normal. Berdasarkan uji homogenitas juga didapatkan bahwa sig $(0.295)>(0.05)$ yang berarti persebaran data homogen. Oleh karena itu, data pretest dan posttest emotional intelligence dianalisis menggunakan statistik parametrik, yaitu Paired Sample T-Test.

Berdasarkan hasil uji beda, diketahui nilai signifikansi (tabel 4) 0.006 ( $p<0.05$ ). Hal ini berarti terdapat perbedaan tingkat pengetahuan emotional intelligence yang signifikan sebelum dan setelah pemberian pelatihan. Dengan demikian, dapat dikatakan bahwa tingkat pengetahuan tentang emotional intelligence atau kecerdasan emosi peserta meningkat setelah pemberian pelatihan.

Pada penilaian evaluasi perilaku yang menggunakan skala RS, dapat disimpulkan bahwa terjadi perubahan resiliensi yang signifikan antara sebelum dan setelah pelatihan diberikan, diketahui nilai signifikansi (Tabel 4) 0.009 ( $<<0.05$ ). Analisis statistik menggunakan statistik parametrik, paired sample t-test karena hasil uji normalitas menunjukkan persebaran data yang normal, dan uji homogenitas menunjukkan sig (0.86) $>$ (0.05) yang berarti data homogen. Hal ini berarti terdapat perbedaan yang signifikan pada tingkat resiliensi diri sebelum dan setelah pemberian pelatihan. Dengan demikian dapat dikatakan bahwa tingkat resiliensi peserta meningkat setelah pemberian pelatihan.

Tabel 4 Analisis Perbedaan skor pretest dan posttest EI dan Resiliensi

\begin{tabular}{llllllr}
\hline Komparasi & t-test & N & Mean & T & df & Sig. (2-tailed) \\
\hline $\begin{array}{l}\text { Pretest \& Posttest } \\
\text { (EI) }\end{array}$ & Pair-test & 19 & -6.89474 & -3.130 & 18 & .006 \\
\hline $\begin{array}{l}\text { Pretest \& Posttest } \\
\text { (Resiliensi) }\end{array}$ & Pair-test & 19 & $-1.28421 \mathrm{E} 1$ & -2.941 & 18 & .009 \\
\hline
\end{tabular}

Berdasarkan uji statistik dengan menggunakan uji regresi linear, didapatkan hasil nilai R (Tabel 5) adalah 0.241 yang berarti pelatihan EI berpengaruh $24.1 \%$. Lalu setelah pelatihan terjadi perubahan nilai $\mathrm{R}$ (Tabel 5) menjadi 0.763 yang berarti pelatihan EI berpengaruh sebanyak $76.3 \%$ setelah pelatihan. 
Lebda Katodhia \& Frikson C. Sinambela | Efektivitas Pelatihan Emotional

Tabel 5 Analisis Pengaruh Pelatihan Emotional Intelligence

\begin{tabular}{lcccccc}
\hline & N & R & $\begin{array}{l}\text { R } \\
\text { Square }\end{array}$ & df & F & Sig. \\
\hline Sebelum Pelatihan & 19 & $.241^{\mathrm{a}}$ & .058 & 18 & 1.052 & $.319^{\mathrm{a}}$ \\
\hline Setelah Pelatihan & 19 & $.763^{\mathrm{a}}$ & .582 & 18 & 23.630 & $.000^{\mathrm{a}}$ \\
\hline
\end{tabular}

Setelah satu minggu pelatihan diberikan, peneliti melakukan follow up. Follow up dilakukan melalui wawancara dan angket yang sama. Hasil wawancara menunjukkan bahwa peserta mulai dapat mengatasi kesulitan hidup dengan emosi dan cara yang positif, meskipun peserta masih mengalami hambatan-hambatan dalam mempraktekkan hasil pelatihan. Adapun hambatan yang dialami oleh para peserta dapat dibagi menjadi dua jenis, yaitu hambatan dari lingkungan dan hambatan dari dalam diri. Hambatan dari lingkungan misalnya, orangtua yang tidak merubah sikap, contohnya, masih sering memarahi anak tanpa sebab yang jelas, sering membanding-bandingkan anak, tidak pernah di rumah, selalu bertangkar bila di rumah, atau saudara yang selalu menyuruh, selalu memarahi, dan tidak pernah memberikan apresiasi. Sebaliknya, beberapa hambatan dari dalam diri meliputi; merasa masalah yang terjadi adalah masalah yang paling berat dan rumit, tidak dapat berhenti memikirkan masalah yang terjadi, dan selalu memunculkan emosi negatif pada setiap keadaan terutama keadaan di dalam rumah.

Terkait data penunjang/ faktor protektif yang muncul dari para peserta juga dapat dibagi menjadi dua jenis, yaitu penunjang yang berasal dari dalam diri dan yang berasal dari lingkungan. Secara spesifik, penunjang yang berasal dari dalam diri ini dapat mencerminkan dua aspek dalam emotional intelligence, yaitu perceiving emotion dan managing emotion. Beberapa peserta mendapatkan dukungan atau dorongan dari dalam diri dengan cara mula memahami dan mengenali emosi yang ada dalam dirinya dan orang lain serta mulai mengelola emosi tersebut sehingga menjadi lebih tenang dan mengambil cara positif untuk beradaptasi dan tangguh menghadapi permasalahan yang terjadi. Sementara itu, penunjang yang berasal dari lingkungan, misalnya keberadaan temanteman yang mendengarkan, adanya extrakulikuler yang disediakan oleh sekolah, adanya guru BK yang dapat mendengarkan keluh kesah peserta, dan adanya tujuan yang mereka gambar saat sesi pelatihan.

Hasil pengisian angket post test dan follow up emotional inteligence memiliki persebaran data yang tidak normal dan juga tidak homogen sig $(0.024)<(0.05)$ sehingga analisisnya menggunakan statistik non-parametrik, Wilcoxon Signed Rank. 
Lebda Katodhia \& Frikson C. Sinambela | Efektivitas Pelatihan Emotional

Tabel 6 Analisis Hasil Pst test dan Follow Up

\begin{tabular}{lll}
\hline & & $\begin{array}{l}\text { Asymp. Sig. } \\
\text { (2-tailed) }\end{array}$ \\
\hline Emotional Intelligence & Post test-follow up & .778 \\
\hline Resiliensi & Post test-follow up & .376 \\
\hline
\end{tabular}

Uji statistik post test dan follow up emotional intelligence menunjukkan signifikansi $0.778>(0.05)$ (tabel 4$)$, hal tersebut berarti tidak ada perbedaan EI yang signifikan antara post test dan follow up. Hal ini berarti pelatihan masih berpengaruh terhadap emotional intelligence peserta setelah satu minggu.

Berdasarkan uji normalitas follow up dan resiliensi, persebaran data normal, namun tidak homogen, sig $(0.007)<(0.05)$ sehingga analisisnya menggunakan statistik non-parametrik, Wilcoxon Signed Rank.

Uji statistik post test dan follow up resiliensi menunjukkan signifikansi $0.376>$ (0.05) (Tabel 4), hal tersebut menunjukkan tidak ada perbedaan yang signifikan pada resiliensi peserta pelatihan saat post test dan follow. Hal ini berarti pelatihan masih berpengaruh terhadap resiliensi peserta setelah satu minggu.

\section{PEMBAHASAN}

Penelitian ini menunjukkan bahwa pelatihan emotional intelligence efektif dalam meningkatkan resiliensi siswa yang melakukan tindakan menyakiti diri sendiri (self injury). Resiliensi umumnya mewakili kapasitas untuk "bounce back" stres atau pesoalan lainnya secara efektif, beradaptasi secara fleksibel dan bahkan tumbuh secara positif dengan menanggapi secara positif kesulitan dalam diri (Block \& Kremen, 1996; Bonanno, 2004, dalam Liu, dkk., 2013). Emotional Intelligence (EI) berfokus pada sifat-sifat kepribadian dan kemampuan yang memungkinkan individu untuk mengatasi perasaan mereka sendiri maupun orang lain (Mayer, Salovey, Caruso, \& Sitarenios, 2001, dalam Apor, dkk., 2015).

Terdapat bukti kuat yang mendukung asosiasi antara resiliensi/ ketahanan dan EI (Liu, dkk., 2013). Matthews et, al (2002) menunjukkan bahwa EI adalah anteseden terhadap resiliensi/ ketahanan (Matthews \& Zeidner, 2004). Armstrong et, al (2011) melakukan penelitian yang mengungkapkan bahwa individu yang rentan memiliki skor EI yang lebih rendah, sedangkan individu yang memiliki resiliensi/ ketahanan memiliki skor EI yang lebih tinggi. Lebih dari itu, inti dari EI adalah kemampuan efektif untuk mengatur emosi seseorang, yang ditemukan dapat meningkatkan ketahanan/ resiliensi individu (New et al., 2009; Tugade \& Fredrickson, 2007). Dengan demikian, Armstrong et, al (2011) 
menunjukkan bahwa EI terhubung langsung dengan resiliensi/ ketahanan. Selain itu, Apor et, al (2015) dalam penelitiannya menemukan hubungan positif antara resiliensi/ ketahanan dan sebagian besar cabang EI.

Pada pelatihan emotional intelligence ditanamkan aspek-aspek emotional intelligence yang diturunkan pada setiap sesi pelatihan melalui berbagai metode. Setiap sesi yang berisi aspek emotional intelligence akan menyasar aspek-aspek yang ada dalam resiliensi. Misalnya aspek pertama yaitu Perceiving emotions/ mengamati emosi yang terfokus untuk meningkatkan self reliance (kemampuan untuk bergantung pada diri sendiri dan mengenal kekuatan serta keterbatasan dirinya). Seseorang yang memiliki self reliant, maka ia yakin pada diri dan kemampuannya. Hal ini terkait dengan Johari Window dimana terdapat empat jendela dalam mengenal manusia (Avin, 1995). Pada sesi ini peserta diminta untuk mengamati emosi dengan membuat SWOT. Mengamati emosi merupakan salah satu cara untuk dapat mengenal diri sendiri.

Sesi kedua yaitu turunan dari aspek Using Emotions yang dapat meningkatkan meaningfulness. . Untuk dapat lebih resilien, kita harus mampu memahami makna atau tujuan hidup kita dengan menggunakan emosi. Seperti yang sudah dipaparkan bahwa seseorang yang memiliki meaningfulness akan melakukan berbagai hal dengan berdasarkan tujuan dan memberi nilai yang bermakna dalam hidupnya. Dalam proses kognitif, tujuan hidup/ meaning of life adalah sumber utama dalam pengaturan diri dan persepsi diri, dan mendukung perilaku adaptif. Pada dasarnya tujuan hidup tidak mengatur perilaku, melainkan memandu individu untuk dapat mengatasi peristiwa stress atau peristiwa negatif dengan lebih mudah melalui sumber daya mereka atau melalui pembuatan keputusan yang sesuai dengan sistem nilai pribadi mereka (McKnight \& Kashdan, 2009). Untuk dapat meningkatkan resiliensi, individu sangat perlu memiliki meaningfulness dimana salah satunya caranya adalah dengan menggunakan emosi secara tepat.

Sesi ketiga yaitu Understanding Emotions yang dapat meningkatkan equanimity dan existensial aloneness, dimana individu harus memahami dan menyadari bahwa hidup adalah sebuah keseimbangan, kadang manusia memungkinkan untuk berada di atas, namun kadang menjadi mungkin berada di bawah, baik pada aspek finansial maupun aspek lainnya. Selain itu, memahami keunikan individu juga merupakan hal penting dilatih.

Dalam memahami keunikan dan keseimbangan dalam kehidupan, sangat penting adanya pemahaman mengenai emosi. Understanding emotions atau pemahaman emosi, adalah kemampuan untuk memahami bahasa emosi dan untuk menghargai hubungan 
yang rumit antara emosi. Keterampilan dasar di bidang ini termasuk melabeli emosi dengan bahasa yang akurat serta mengenali persamaan dan perbedaan antara label emosi dan emosi itu sendiri. Menafsirkan makna dan asal-usul emosi (misalnya, kesedihan merupakan hasil dari kehilangan, sukacita di dapat dari tercapainya suatu tujuan) dan memahami perasaan kompleks seperti suasana hati atau emosi yang simultan (merasa tertarik dan bosan), atau memadukan perasaan (misalnya, penghinaan sebagai kombinasi jijik dan kemarahan).

Mengenali transisi antara emosi (misalnya, kesedihan dapat menyebabkan keputusasaan yang dapat menyebabkan kehancuran) dan kemampuan untuk peka terhadap variasi antar emosi, seperti perbedaan antara bahagia dan gembira adalah komponen yang sangat penting. Selain itu, pemahaman juga meliputi kemampuan untuk mengenali dan menggambarkan bagaimana emosi berkembang dari waktu ke waktu, seperti betapa sedihnya bisa berubah menjadi kesenangan. Ketika seseorang mampu memahami emosinya yang terus berkembang dalam satu waktu, maka akan lebih mudah bagi dirinya untuk dapat resilien ketika dihadapkan pada persoalan yang rumit.

Sesi terakhir dan merupakan aspek terakhir dari emotional intelligence adalah Managing Emotions yang dapat meningkatkan perseverance. Perseverance merupakan tindakan dalam bentuk ketekunan meskipun dalam situasi sulit dan kehilangan semangat. Seseorang yang memiliki perseverance bila mengalami kesulitan atau keputusasaan akan tetap menginginkan untuk melanjutkan perjuangannya dan melaksanakannya dengan disipin. Ketekunan adalah tindakan yang dapat dilakukan oleh seseorang untuk dapat menjadi lebih resilien. Ketahanan dan ketekunan adalah kompetensi perilaku yang penting ketika individu harus mengatasi hambatan yang signifikan. Kapasitas untuk menjadi fleksibel serta mendemonstrasikan berbagai tanggapan terhadap kesulitan akan secara dramatis berdampak pada tingkat kesuksesan masa depan kita.

Salah satu cara agar individu mampu untuk dapat tetap melanjutkan perjuangan meskipun mengalami kesulitan adalah dengan mengelola emosi. Managing emotions atau mengelola emosi, terdiri dari kemampuan untuk mengatur emosi dalam diri kita sendiri dan orang lain. Managing emotions juga merupakan kemampuan untuk bersikap terbuka terhadap perasaan, menerima kesedihan maupun kesenangan, membawa mereka ke dalam diri sendiri dan orang lain sehingga dapat meningkatkan pemahaman dan pertumbuhan pribadi.

Menurut Salovey dan Mayer (1997), kecerdasan emosional adalah bagian dari kecerdasan sosial (social intelligence) yang meliputi kemampuan untuk memonitor perasaan dan emosi diri sendiri dan orang lain, membedakannya, dan menggunakan 
informasi emosi tersebut untuk memandu proses berpikir dan bertingkah laku (Mayer, J. D., \& Salovey, 1997). Berdasarkan hasil penelitian, peserta seluruhnya mampu memonitor perasaan dan emosi diri sendiri maupun orang lain, yang terbukti dari hasil penugasan yang diberikan selama pelatihan, selain itu peserta juga mampu membedakan setiap emosi yang dirasakannya melalui hasil refleksi yang dilakukan setelah kegiatan. Setelah mengetahui emosi-emosi yang ada di dalam diri maupun pada orang lain, peserta mulai menggunakan emosi tersebut dalam merespon atau melakukan sesuatu. Misalnya lebih memikirkan perasaan orangtua ketika akan melakukan self injury.

Menurut Wagnild dan Young (1993) resiliensi ialah kemampuan seseorang untuk beradaptasi dalam menghadapi kesulitan hidup. Menurut Alva (1991, dalam Cassidy, 2015) siswa yang memiliki ketangguhan atau daya tahan adalah mereka yang mempertahankan prestasi dan kinerja serta masih memiliki motivasi tinggi bahkan ketika dihadapkan dengan peristiwa dan kondisi yang membuat mereka memiliki permasalahan. Waxman et al. (2003, dalam Cassidy, 2015) siswa yang memiliki daya tahan akan tetap berhasil di sekolah meskipun berada dalam kondisi yan buruk. Menurut Cassidy (2015), daya tahan siswa yang menghadapi kondisi kurang kondusif dikenal sebagai resiliensi (Cassidy, 2015). Setelah pelatihan dilakukan, melalui wawancara, peserta mengaku bahwa mereka lebih mampu untuk menghadapi kondisi di luar diri yang kurang kondusif dengan cara mengatur emosi mereka agar mampu berpikir logis.

Hasil pelatihan menunjukkan adanya perubahan yang signifikan pada resiliensi peserta pelatihan. Hasil penelitian ini sejalan dengan hasil penelitian yang dilakukan oleh Apor, Pardeller, Kemmler, dan Hofer (2015) yang mengemukakan bahwa terdapat hubungan yang positif antara emotional intelligence dengan resiliensi pada populasi perawat pasien dengan serious mental illness (SMI). Penelitian tersebut mengemukakan bahwa korelasi positif antara EI dengan resiliensi menjadi target potensial dalam pendidikan dan pelatihan untuk memperkuat resiliensi pada individu yang sehat. Penelitian lain yang dilakukan oleh Fauziya dan Daulima (2017) juga mengemukakan bahwa terdapat hubungan yang positif antara kecerdasan emosi dengan resiliensi penyitas banjir di Indramayu, penyitas dengan kecerdasan emosi tinggi memiliki peluang lebih besar untuk mampu beresiliensi dengan baik (Fauziya \& Daulima, 2017).

Sejalan dengan itu, penelitian Foumany dan Salehi (2015) mengemukakan bahwa hasil penelitian menunjukkan bahwa perubahan dan kontrol emosi dapat membantu mencapai keterampilan dan kapasitas resiliensi (Foumany \& Salehi, 2015). Penelitian ini juga mengemukakan bahwa terdapat hubungan positif yang signifikan antara kecerdasan emosi dan resiliensi. Kecerdasan emosional dapat memperkirakan resiliensi individu 
sehingga diharapkan studi selanjutnya akan berfokus pada kapasitas kecerdasan emosional. Menurut struktur kecerdasan emosional, dapat dinyatakan bahwa mempersepsikan dan mengekspresikan emosi, mengatur emosi, mengambil keuntungan dari emosi, dan mengelola emosi pada berbagai situasi termasuk situasi beresiko dapat menjadi faktor pelindung yang dapat meningkatkan resiliensi individu (Foumany \& Salehi, 2015). Individu yang resilien dapat mengendalikan emosi mereka, mengatasi kebingungan, dan membantu mencapai lebih banyak kepuasan dalam kehidupan serta penyesuaian yang lebih baik. Oleh karena itu, intervensi berbasis kecerdasan emosional dalam dunia pendidikan sangat dianjurkan bagi penelitian selanjutnya (Foumany \& Salehi, 2015).

Institusi diharapkan dapat terus mempromosikan atau mengadakan seminar rutin mengenai pendampingan untuk orangtua terkait pentingnya pendidikan anak di rumah, hal ini bertujuan agar pola pikir orangtua dapat berubah sehingga tidak menomorduakan pendidikan anak dan mulai memperhatikan pendidikan anak di dalam rumah. Pihak sekolah dapat menekankan pada para orangtua bahwa mengajar anak-anak tidak hanya bisa difokuskan pada anak, tetapi juga harus mempertimbangkan dan melibatkan lingkungan di sekitar anak terutama keluarga. Tanggung jawab untuk pendampingan orangtua juga tidak bisa dibebankan seluruhnya pada pengajar/ guru. Terkait hal tersebut, instansi mungkin dapat mempertimbangkan agar membuat satu program di bawah naungan dinas pendidikan yang khusus menangani permasalahan terkait lingkungan anak yang tidak mendukung kegiatan belajar mengajar, terutama lingkungan anak-anak yang berada di kawasan pinggiran. Sekolah dapat mengadakan seminar atau pelatihan untuk guru agar guru dapat mengaplikasikan hubungan yang humanis di sekolah sehingga siswa dapat menceritakan masalahnya di rumah kepada guru di sekolah. Penanganan siswa bermasalah tidak hanya ditangani oleh guru BK, melainkan semua tenaga pendidik yang berada di sekolah.

\section{SIMPULAN}

Dari hasil penelitian yang dilakukan dapat disimpulkan bahwa selama proses pelatihan, sebagian besar peserta mampu menunjukkan sikap yang baik terkait dengan materi, aktivitas-aktivitas, dan proses selama pelatihan. Hasil observasi menunjukkan bahwa hampir seluruh peserta mengalami peningkatan keterlibatan setiap sesinya. Peserta pelatihan menunjukkan perubahan pada kecerdasan emosi dan resiliensi sebelum dan setelah pelatihan, serta efek pelatihan tidak berubah sampai pada saat follow up dilakukan. Berdasarkan hasil perhitungan, diketahui bahwa skor emotional intelligence 
peserta mengalami peningkatan dan sejalan dengan itu skor resiliensi diri juga mengalami peningkatan. Peserta yang memiliki peningkatan skor kecerdasan emosi, tetapi skor resiliensi diri tetap atau menurun, menunjukkan bahwa terdapat variabel-variabel lain yang dapat memengaruhi resiliensi diri peserta pelatihan. Dari hasil follow up melalui wawancara, ditemukan bahwa terdapat dua variabel lain yang berdampak pada resiliensi, yaitu ketidakpahaman peserta akan materi yang disampaikan dan kurangnya konsentrasi peserta saat pelatihan berlangsung.

Hasil follow up menunjukkan bahwa peserta pelatihan menjadi semakin gigih atau tangguh dalam menghadapi permasalahan sehari-hari, terutama karena adanya tujuan yang jelas sehingga mereka tidak mau terus berlarut dalam kesedihan atau masalah yang mereka hadapi. Selain itu, para peserta juga tidak mudah memunculkan emosi negatif dalam menghadapi hambatan/ masalah, mereka berusaha mengelola emosi dan mencari cara-cara positif yang dapat menjadi solusi atas kendala yang mereka hadapi. Dengan demikian, dapat disimpulkan bahwa pelatihan emotional intelligence efektif dalam meningkatkan resiliensi siswa yang melakukan tindakan menyakiti diri sendiri (self injury). Adanya emotional intellgence membuat para peserta semakin gigih atau resilien dalam menghadapi permasalahan sehari-hari, sehingga membuat peserta tidak akan mengulangi perilaku menyakiti diri sendiri. 


\section{DAFTAR PUSTAKA}

Alfonso, M., \& Dedrick, R. E. (2010). Self-injury among early adolescents. American Journal of Health Education, 41(2), 74-84. https://doi.org/10.1080/19325037.2010.10599131

Ali, M. (2010). Metodologi Dan Aplikasi Riset Pendidikan. Bandung: Pustaka Cendikia Utama.

Armstrong, A. R., Galligan, R. F., \& Critchley, C. R. (2011). Emotional intelligence and psychological resilience to negative life events. Personality and Individual Differences, 51(3), 331-336. https://doi.org/10.1016/j.paid.2011.03.025

Avin. (1995). PENGENALAN DIRI Avin Fadilla Helmi. 13-19.

Campo, M., Laborde, S., \& Weckemann, S. (2015). Emotional intelligence training: Implications for performance and health Complimentary Contributor Copy. Advances in Psychology Research, (May 2016).

Cassidy, S. (2015). Resilience building in students: The role of academic self-efficacy. Frontiers in Psychology, 6(NOV), 1-14. https://doi.org/10.3389/fpsyg.2015.01781

Estefan, G., \& Wijaya, Y. D. (2014). Gambaran Proses Regulasi Emosi Pada Pelaku Self Injury. Jurnal Psikologi, 12(1), 26-33.

Fauziya, L. I., \& Daulima, N. H. C. (2017). Hubungan Kecerdasan Emosi Dengan Resiliensi Penyintas Banjir. Jurnal Keperawatan Indonesia, 20(3), 148-157. https://doi.org/10.7454/jki.v20i3.624

Foumany, G. H. E., \& Salehi, J. (2015). The relationship between emotional intelligence and life satisfaction and the mediatory role of resiliency and emotional balance among the students of Zanjan University. Acta Medica Mediterranea, 31(7), 1351-1357.

Frajo-Apor, B., Pardeller, S., Kemmler, G., \& Hofer, A. (2016). Emotional Intelligence and resilience in mental health professionals caring for patients with serious mental illness. Psychology, Health and Medicine, 21(6), 755-761. https://doi.org/10.1080/13548506.2015.1120325

Kuipera, N. A. (2012). Humor and resiliency: Towards a process model of coping and growth. Europe's Journal of Psychology, 8(3), 475-491. https://doi.org/10.5964/ejop.v8i3.464

Liu, Y., Wang, Z., \& Lü, W. (2013). Resilience and affect balance as mediators between trait emotional intelligence and life satisfaction. Personality and Individual Differences, 54(7), 850-855. https://doi.org/10.1016/j.paid.2012.12.010

Matthews, G., \& Zeidner, M. (2004). Book review. 32, 109-111. https://doi.org/10.1016/S0160-2896(03)00059-X

Mayer, J. D., \& Salovey, P. (1997). What is emotional intelligence? In P. Salovey \& D. Sluyter (Eds.), Emotional development and emotional intelligence: Educational implications. New York, NY: Basic Books. 
McKnight, P. E., \& Kashdan, T. B. (2009). The importance of functional impairment to mental health outcomes: A case for reassessing our goals in depression treatment research. Clinical Psychology Review, 29(3), 243-259. https://doi.org/10.1016/j.cpr.2009.01.005

Sahrah, A., \& Yuniasanti, R. (2018). Efektivitas Pelatihan Pemberian Dukungan Sosial pada Walinapi dengan Metode Bermain dan Permainan Peran. Jurnal Psikologi, 45(2), 151. https://doi.org/10.22146/jpsi.28038

Santrock, J. W. (2001). Life Span Development (Perkembangan Masa Hidup, Jilid 2). Jakarta: Erlangga.

Setyowati, A., Hartati, S., \& Sawitri, D. R. (2010). Hubungan Antara Kecerdasan Emosional Dengan Resiliensi Pada Siswa Penghuni Rumah Damai. Jurnal Psikologi Undip, 7(1), 67-77. https://doi.org/10.14710/jpu.7.1.67-77

Shapiro, L. E. (1997). Mengajarkan Emotional Intelligence pada Anak. Jakarta: Gramedia Pustaka Utama.

Tirto.id. (2018). Mengiris Tangan Sakiti Diri Bisa Jadi Anak Depresi. https://Tirto.Id/Mengiris-Tangan-Sakiti-Diri-Bisa-Jadi-Anak-Depresi-C8KH.

Wagnild, G., \& Young, H. (1993). <Wagnild_1993_Resilience_Scale_2.Pdf>. Journal of Nursing Measurement, 1(2), 165-178. https://doi.org/10.1016/j.apnu.2010.05.001 